\title{
THE PECULIARITIES OF THE DEVELOPMENT OF THE EMOTIONAL AND FIGURATIVE THINKING OF FUTURE TEACHERS OF MUSICAL ART
}

\section{Pohoda Olena ${ }^{1}$ Tsuranova Oksana ${ }^{2}$}

DOI: https://doi.org/10.30525/978-9934-571-89-3_21

Society, advanced theory and practice of pedagogical education put forward the latest updated requirements for the improvement of the existing state of instrumental and performing training of the future teacher of musical art.

The content of training of the students of art specialties oat higher educational institutions is determined by the specific practice work of music teachers at institutions of secondary education that combines performing and instrumental, vocal and choral and musical education, and has to be performed at musical art lessons and during out-of-school hours. The success of such a poly-dimensional activity depends on the level of the development of emotional and figurative thinking, on the future musical art teacher's possession of certain performing skills and abilities, the formation and creation of which is carried out in the process of education at a higher educational institution. The formation of an active creative personality is one of the main tasks of the musical and pedagogical education of the future specialist.

The analysis of the state of the practical training of future teachers of musical art, the work on research sources, in particular those made by G. Altshuller, L. Archazhnikova, M. Bezrukykh, S. Yefimova, N. Karamysheva, A. Kovalenko, M. Nazarenko, N. Poddiakov, Y. Trofimov, V. Cherkasov and others, gave an opportunity to define a range of questions concerning the necessity of the

\footnotetext{
${ }^{1}$ Public Institution "Kharkiv Humanitarian Pedagogical Academy" Kharkiv Regional Council, Ukraine

${ }^{2}$ Public Institution "Kharkiv Humanitarian Pedagogical Academy"

Kharkiv Regional Council, Ukraine
} 
development of emotional and figurative thinking of future teachers of musical art as the defining condition for their professional readiness for various types of creative activities in the process of teaching musical art at institutions of general secondary education.

The purpose of the present work is to reveal some peculiarities of the development of emotional and figurative thinking of the teachers of musical art in the process of their professional education. The research used the methods of analysis and generalization, through which the features of the above-mentioned problems were identified and the appropriate conclusions were drawn.

The content of the professional training of students of musical departments of art institutes and higher education faculties is determined by the specifics of the practical activity of the future teacher of musical art at institutions of general secondary education, which is to combine musical and theoretical, vocal and choral, and instrumental and performing work. The main task of the teachers of art faculties is the formation and development of students' skills necessary for the future teacher for educational, musical and tutorial work with schoolchildren. The teacher of a special musical instrument is a professional musician; his/her pedagogical experience often consists of searches, finds and losses that occur when communicating with a student. In the classroom there is often only a transfer and accumulation of knowledge, information, and this knowledge is useful, but not enough to form a creative personality. The teacher teaches the student instrumental-performing arts in a single process of the reproduction of musical sounding [4]. The knowledge of the elements of music science can be written, classified; the ability can be demonstrated, repeated, and revised. But these two important components of the educational process are not enough to achieve the desired result. There is a special sphere of the knowledge of the teacher that is not so easily accessible and comprehensible - this is a sphere of figurative thinking, without which the performance of musical compositions cannot be defined as a creative activity. From the experience of teaching practice, it is well known that knowledge becomes really strong if the student gained certain information through the independent thinking, emotional and figurative thinking and passion during the classroom lessons that are aimed at forming the creative activity of future teachers of musical art, developing their emotional and figurative thinking.

Emotional and figurative thinking is an artistic perception of the world, filled with fantasy and personal feelings of the personality. During piano lessons, it is appropriate to use program music, which helps future musical professionals to feel the figurative and emotional content of the composition better. The name of the plays related to applied genres (song, dance, and march), in a certain way, helps to imagine a circle of the figurative content of musical compositions. Studying, in particular, plays from the cycles for children contributes to the development of the artisticfigurative world of student-musicians, expands their musical horizons, and develops emotional and figurative thinking, which depends to a certain extent on the ability of a future specialist to penetrate into the emotional content of a musical composition. And although they note different types of musical thinking: with the advantage of an emotionally sensual or abstract-logical attitude to music, it is important to target the 
student's attention to the development of a less developed ability. The scientist N. Poddiakov observes that the distinctive feature of figurative thinking is the mental process in it, directly related to the perception of the environment. Students have a need for the emotional saturation of musical compositions, the changes in emotional states, and the disclosure of a diverse range of feelings [5]. Certain knowledge of the basics of performing art helps to create a holistic artistic image of a musical composition, in particular: musical terms help to reveal the figurative content of a composition. It is appropriate to use the approach of emotional colouring of chords, sounding of consonants and dissonances, major and minor; means of musical expression (fret, timbre, rhythm, tempo, dynamic shades, and performing strokes) that contribute to the disclosure of the nature of the composition, a quick study of the emotionally painted musical material by heart. In the process of acquiring knowledge and skills by the students, it is extremely necessary to form the artistic taste and ability to hear the stylistic features of composers in them [1].

Thus, one of the manifestations of level of musical education of a teacher of musical art is his/her performing culture, which is determined not only by the level of the mastery of a musical instrument, but also by the ability to comprehend musical material and, creatively interpreting it, to bring it to the audience. The development of emotional and figurative thinking of future teachers can be called a general performing-pedagogical problem. Therefore, one should look for new, effective forms of the developing education, the form of the joint creativity of the teacher and student. In the course of studies with a student the teacher needs to ensure the development of spirituality and the general culture of the future specialist in musical art to be held through the formation of emotional and figurative thinking.

\section{References:}

1. Cherkasov V.F. (2000). Teorija i metodyka muzychnoji osvity: Navchaljnyj posibnyk [Theory and methodology of music education: a manual]. Ternopil: Navchaljna knygha - Boghdan. (in Ukrainian)

2. Karamysheva N.V. (2002). Loghika. Piznannja. Evrystyka: Posibnyk dlja studentiv ta aspirantiv [Knowledge. Heuristics: a Guide for Students and PhD Students]. Lviv: Astroljabija. (in Ukrainian)

3. Kovalenko A.B. (1994). Psykhologhija rozuminnja tvorchykh zadach [Psychology of understanding creative tasks]. Kiev: Lybidj. (in Ukrainian)

4. Nazarenko M.P. (2009). Formuvannja ghotovnosti majbutnjogho vchytelja muzyky do instrumentaljno-vykonavsjkoji dijaljnosti na osnovi integhratyvnogho pidkhodu [Formation of readiness of the future teacher of music for instrumental-performing activity on the basis of an integrative approach] (PhD Thesis), Kirovograd: KDPU im. V. Vynnychenka.

5. Podd“"yakov N.N. (1973). O formirovanii naglyadno-obraznogo myshleniya [On the formation of visual-figurative thinking]. Questions psychologists, vol. 3, pp. 114-117.

6. Trofimov Ju.L. (2008). Psykhologhija. Pidruchnyk [Psychology. Textbook]. Kiev: Lybidj. (in Ukrainian) 